\title{
Status of soil heavy metals contamination using contamination indices in shallot fields
}

\author{
Triyani Dewi ${ }^{1,2}$, Edhi Martono ${ }^{3}$, Eko Hanudin ${ }^{4 *}$, and Rika Harini ${ }^{5}$ \\ ${ }^{1}$ Graduate School of Environmental Science, Universitas Gadjah Mada, Pogung Sinduadi Yogyakarta \\ 55284, Indonesia \\ ${ }^{2}$ Indonesian Agricultural Environment Research Institute, Jl. Jakenan-Jaken KM 5, Pati, Central Java, \\ Indonesia \\ ${ }^{3}$ Department of Plant Protection, Faculty of Agriculture, Universitas Gadjah Mada, Bulaksumur, \\ Yogyakarta 55281, Indonesi. \\ ${ }^{4}$ Department of Soil Science, Faculty of Agriculture, Universitas Gadjah Mada, Bulaksumur, \\ Yogyakarta 55281, Indonesia. \\ ${ }_{5}^{5}$ Department of Environmental Geography, Faculty of Geography, Universitas Gadjah Mada, Sekip \\ Utara, Bulaksumur, Yogyakarta 55281, Indonesia.
}

\begin{abstract}
Monitoring and assessment of heavy metal concentrations in shallot fields are needed to evaluate the potential risk of contamination due to heavy metals. This study aims to define the status of heavy metal contamination in shallot fields using contamination indices. A total of 184 soil samples $(0-20 \mathrm{~cm})$ were taken from shallot fields in Brebes Regency, Central Java. The soil samples were analyzed for the concentration of five heavy metals $(\mathrm{Cd}, \mathrm{Pb}, \mathrm{Ni}, \mathrm{Cr}$, and $\mathrm{Co})$ with $\mathrm{HNO}_{3}$ and $\mathrm{HClO}_{4}$ extracts and measured using AAS. Assessment of the status of heavy metals contamination in the soil using contaminant factor (CF), geo-accumulation index (I-geo), and pollution load index (PLI). The mean concentration in shallot fields showed the following order $\mathrm{Cr}>\mathrm{Ni}>\mathrm{Pb}>\mathrm{Co}>\mathrm{Cd}$ and the concentration were still below critical limit values. Four metals are $\mathrm{Pb}, \mathrm{Cr}$, $\mathrm{Co}$, and $\mathrm{Ni}$ are low contamination $(\mathrm{CF}<1)$, while $\mathrm{Cd}$ is considerable until very high contamination factor. Based on I-geo values, shallot fields are practically uncontaminated of $\mathrm{Pb}, \mathrm{Co}, \mathrm{Ni}$, and $\mathrm{Cr}(\mathrm{I}-\mathrm{geo}<1)$, meanwhile the status of $\mathrm{Cd}$ is uncontaminated to moderately contaminated $(0<\mathrm{I}$-geo $<1)$. Generally, the shallot fields in Brebes Regency, Central Java is unpolluted with five metals $(\mathrm{PLI}<1)$.
\end{abstract}

\section{Introduction}

Heavy metal contaminations in agricultural lands have the potential to harm the surrounding environment and human health due to anthropogenic activities. The source of metals comes from industry and agricultural activities (application of fertilizers and pesticides that contain heavy metals [1-2]. Thus far, the practices of intensive agriculture including uncontrolled application of fertilizer and pesticide a lot to find shallot farmers in Brebes Regency.

\footnotetext{
* Corresponding author: ekohanudin@ugm.ac.id
} 
In order to get the right solution to heavy metal contamination in soil, there is a need to identify and evaluate the role of both natural and anthropogenic factors, and the potential ecological risk posed by individual metal. Several methods have been developed to measure environmental quality [3-4]. The often used indices consist of two groups, which are single indices and total complex indices. The single indices as indicators of soil contamination such as geo-accumulation index, contaminant factor, enrichment factor, and pollution index. While total complex indices of contamination are calculated as multielement based on single pollution like pollution load index (PLI), degree of contamination, potential ecological risk index (PERI), and integrated pollution index $[2,5,6]$

This study aims to define the status of heavy metal contamination in shallot fields using contamination indices including contaminant factor (CF), geo-accumulation index (I-geo), and pollution load index (PLI).

\section{Materials and methods}

\subsection{Description of the research area}

The research was conducted in Brebes Regency on the northern coast of Central Java, Indonesia, stretching from $6^{\circ} 44^{\prime}$ to $7^{\circ} 21^{\prime}$ S and from $108^{\circ} 41^{\prime}$ to $109^{\circ} 11^{\prime} \mathrm{E}$. A map showing the soil sampling points is presented in Figure 1. The area study is spread of seventeen subdistricts. The southern part is mostly dominated by the highlands, while the northern part is located in the lowlands.

The study was conducted from August until December 2019. Based on the 2019 data, Brebes receives a total rainfall of $3,729 \mathrm{~mm}$, with the highest occurring in January. There are approximately 172 rainy days, most of which are recorded in March and December. Inceptisols (USDA soil taxonomy classification) are the predominant soil developing in the research location. A map of the soil sampling location of shallot fields in Brebes Regency is shown in Figure 1.

\subsection{Soil sampling}

Soil sampling on shallot fields was carried out in eight sub-districts in Brebes Regency, Central Java, namely Losari, Tanjung, Bulakamba, Wanasari, Brebes, Jatibarang, Larangan, and Ketanggungan with 21,12,36,18,11,6,38, and 42 soil samples respectively. 184 of total soil samples were obtained from the shallot field as shown in Table 1. Topsoil samples were taken at a depth of 0-20 cm, and five sub-samples were collected from 50-100 acres of land using a soil auger. These soil samples were thoroughly mixed and bulked. The bulk samples were reduced to about $1-2 \mathrm{~kg}$ and labeled according to the soil observation procedure. GPS (global position system) was used to record the soil sampling coordinates. Upon soil collection, all samples were first air-dried in the shade, ground with a mortar and pestle, filtered with a $0.5-\mathrm{mm}$ sieve, then analyzed at an integrated laboratory at the Indonesian Agricultural Environment Research Institute (IAERI), Jakenan, Central Java, Indonesia. 
Table 1. Description of a research area

\begin{tabular}{|l|c|c|c|}
\hline $\begin{array}{c}\text { Sampling location } \\
\text { (regency) }\end{array}$ & Number of samples & $\begin{array}{c}\text { Harvested area of } \\
\text { shallot (ha) }\end{array}$ & $\begin{array}{c}\text { Production of shallot } \\
\text { (ton) }\end{array}$ \\
\hline Losari & 21 & 703 & $7,702.3$ \\
\hline Tanjung & 12 & 1,689 & $15,266.0$ \\
\hline Bulakamba & 36 & 4,691 & $43,264.3$ \\
\hline Wanasari & 18 & 5,729 & $65,641.0$ \\
\hline Brebes & 11 & 4,087 & $40,870.0$ \\
\hline Jatibarang & 6 & 1,017 & $10,652.1$ \\
\hline Ketanggungan & 42 & 1,769 & $20,729.2$ \\
\hline Larangan & 38 & 6,978 & $77,186.0$ \\
\hline Total & 184 & 26,663 & $281,310.9$ \\
\hline
\end{tabular}

\subsection{Chemical analysis}

The total heavy metal contents $(\mathrm{Cd}, \mathrm{Co}, \mathrm{Ni}, \mathrm{Pb}$, and $\mathrm{Cr})$ in the soil were measured using the $\mathrm{HNO}_{3}$ and $\mathrm{HClO}_{4}$ mixture for digestion. The resultant liquid extract was measured with an atomic absorption spectrometer (AAS) and then compared with the standard series of each heavy metal from Merck. Total metals of $\mathrm{Pb}, \mathrm{Cd}, \mathrm{Co}, \mathrm{Cr}$, and $\mathrm{Ni}$ concentrations were calculated using the formula below:

Total heavy metals $\left(\mathrm{mg} \mathrm{kg}^{-1}\right)=C$ curve $x \frac{V}{W} \times f p \times f k$

where $C$ curve is heavy metal concentration obtained from the AAS $\left(\mathrm{mg} \mathrm{kg}^{-1}\right), V$ is the final extractant volume $(\mathrm{ml}), W$ is sample weight $(\mathrm{g}), f p$ is dilution factor, and $f k$ is the correction factor for sample moisture content [7].

\subsection{Quantification of soil contamination}

The index of potential risk is a comprehensive way to assess the soil quality and determine the accumulation of heavy metals, due to anthropogenic activities or natural processes This index is also an effective tool to assign the level of contamination in soil with I-geo (geoaccumulation index), CF (contaminant factor), and PLI (pollution load index) [8-10].

Table 2. Indices of soil contamination in this study

\begin{tabular}{|l|l|l|}
\hline Index & Formulation & Explanation \\
\hline $\begin{array}{l}\text { Contaminant factor } \\
(\mathrm{CF})\end{array}$ & $\mathrm{CF}=C s / C b$ & $\begin{array}{l}\text { Cs is metal concentration in } \\
\text { soil; Cb is the background value } \\
\text { of metals }\end{array}$ \\
\hline $\begin{array}{l}\text { Geoaccumulation } \\
\begin{array}{l}\text { Index } \\
\text { (Müller,1981) }\end{array}\end{array}$ & $\mathrm{I}$-geo $=\log _{2}[C n / 1.5 B n]$ & $\begin{array}{l}\text { Cn: concentration of metal in } \\
\text { soil; Bn: geochemical } \\
\text { background concentration of the } \\
\text { metal; } 1.5 \text { : correction factor }\end{array}$ \\
\hline $\begin{array}{l}\text { Pollution load } \\
\text { index (PLI) }\end{array}$ & $\mathrm{PLI}=\sqrt[n]{(C F 1 x C F 2 x C F 3 x \ldots . . x C F n)}$ & $\begin{array}{l}\text { CF is contamination factor; } \mathrm{n} \text { is } \\
\text { the number of heavy metals }\end{array}$ \\
\hline
\end{tabular}

Indices of soil contamination are summarized in Table 2 where the calculation method and classes of contamination are described for $\mathrm{CF}$, I-geo, and PLI values. CF $<1$ refers to weak contamination, $1<\mathrm{CF}<3$ means moderate contamination, $3<\mathrm{CF}<6$ means high contamination, and $\mathrm{CF}>6$ is very high contamination. The level index for I-geo value that is $<0$ practically uncontaminated; $0-1=$ uncontaminated to low contaminated; $1-2=$ moderately 
contaminated; $2-3=$ highly contaminated; 3-4 = heavily contaminated, 4-5 very heavily contaminated; and $>6$ extremely contaminated. According to CF value, the PLI was categorized as $<1$ unpolluted and $>1$ polluted $[11,12]$.

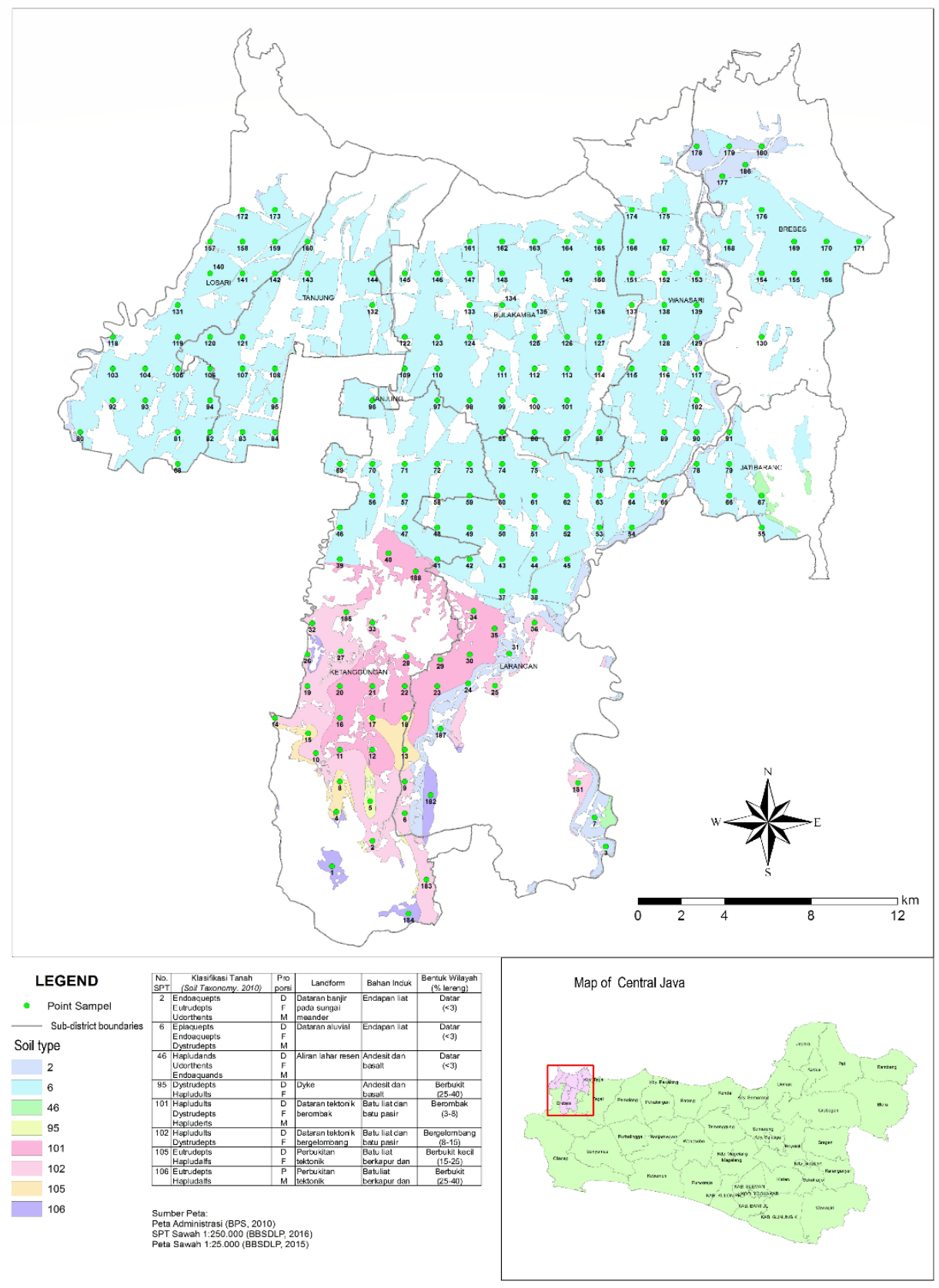

Fig 1. Soil sampling location in Brebes Regency, Central Java 


\section{Result and discussion}

The heavy metals concentration in the shallot fields is shown in Figure 2. Cr concentration was found higher than other metals, where the minimum concentration was $10.40 \mathrm{mg} \mathrm{kg}^{-1}$ and the maximum was $49.55 \mathrm{mg} \mathrm{kg}^{-1}$. Meanwhile, the concentration of $\mathrm{Cd}$ was the lowest compared to other heavy metals and almost homogenous data/ values in all sample locations was $0.99-2.31 \mathrm{mg} \mathrm{kg}^{-1}$.

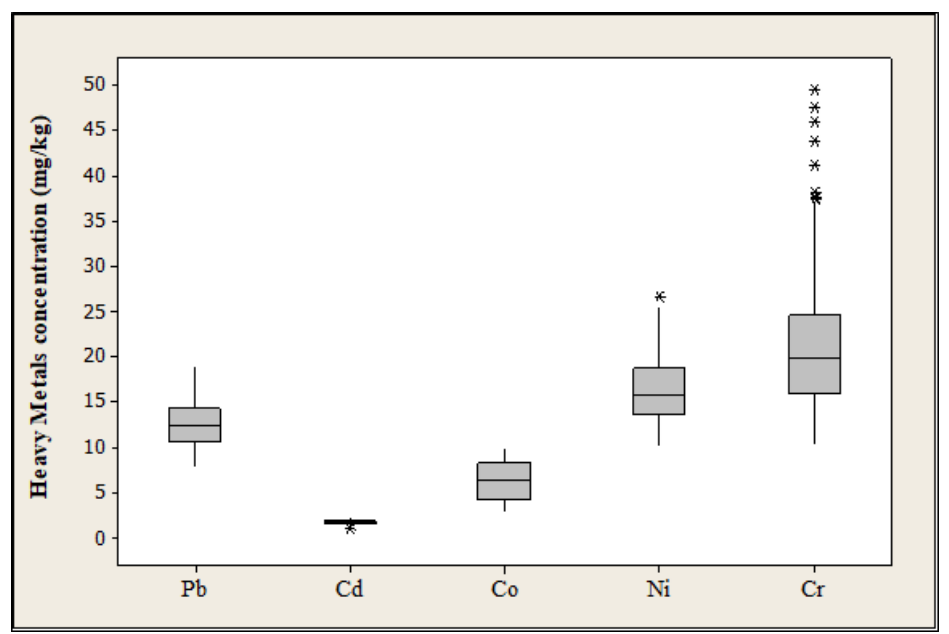

Fig 2. Box and whisker-plot of heavy metals concentration in shallot fields

The mean concentration of heavy metals following $\mathrm{Cr}>\mathrm{Ni}>\mathrm{Pb}>\mathrm{Co}>\mathrm{Cd}$ with 21.52 $\pm 7.42 \mathrm{mg} \mathrm{kg}-^{1} ; 16.22 \pm 3.53 \mathrm{mg} \mathrm{kg}_{-}{ }^{1} ; 12.53 \pm 2,50 \mathrm{mg} \mathrm{kg}_{-}{ }^{1} ; 6.33 \pm 2,17 \mathrm{mg} \mathrm{kg}_{-}{ }^{1} ;$ and 1.78 $\pm 0,27 \mathrm{mg} \mathrm{kg}_{-}{ }^{1}$ respectively. Heavy metals concentration of $\mathrm{Cr}, \mathrm{Pb}, \mathrm{Ni}$, and $\mathrm{Co}$ still lower than background value of $95,17,68$, and $19 \mathrm{mg} \mathrm{kg}^{-1}$ respectively. While the mean concentration of Cd higher background value is $0.3 \mathrm{mg} \mathrm{kg}-1$.

The mean concentration of $\mathrm{Pb}, \mathrm{Co}, \mathrm{Cd}, \mathrm{Ni}$, and $\mathrm{Cr}$ in shallot fields of Brebes Regency of each sub-district is presented in Figure 3. The five heavy metals concentration were still considered normal. According to Alloway [13], the critical limit for $\mathrm{Pb}, \mathrm{Co}$, and $\mathrm{Cd}$ are respectively $<100 \mathrm{mg} \mathrm{kg}^{-1},<25 \mathrm{mg} \mathrm{kg}^{-1},<3 \mathrm{mg} \mathrm{kg}^{-1}$, and $<75 \mathrm{mg} \mathrm{kg}^{-1}$ for $\mathrm{Cr}$ and $\mathrm{Ni}$. 

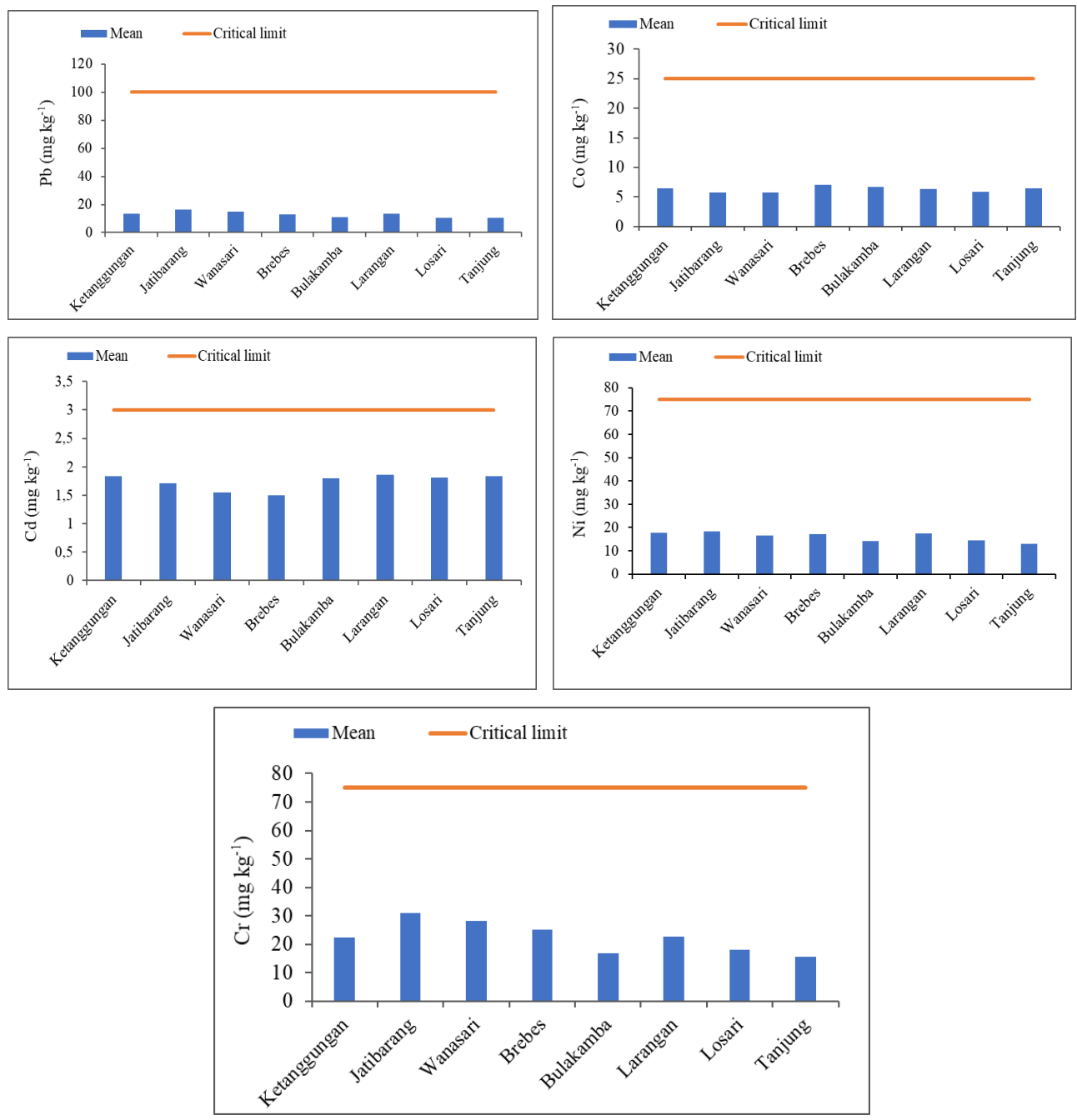

Fig 3. Mean concentration of heavy metals in shallot fields in some sub-district, Brebes Regency

Monitoring and assessment of heavy metal concentrations in agricultural soil are essential to evaluate the potential risk of contamination due to heavy metals. The potential risk index can be used as a tool to control the level of contamination in the agricultural soil, through contaminant factor, geo-accumulation index, and pollution load index $[9,14,15]$. 
Table 2. Concentration and contamination indices of heavy metals in shallot fields, Brebes Regency, Central Java $(\mathrm{n}=184)$

\begin{tabular}{|c|c|c|c|c|c|c|}
\hline \multirow{2}{*}{$\begin{array}{l}\text { Heavy } \\
\text { metals }\end{array}$} & \multirow{2}{*}{ Statistic } & Concentration & Critical & $\mathbf{B V}^{* *}$ & \multicolumn{2}{|c|}{ Contamination indices } \\
\hline & & \multicolumn{3}{|c|}{$\mathrm{mg} \mathrm{kg}^{-1}$} & $\mathbf{C F}$ & I-geo \\
\hline \multirow[t]{3}{*}{$\mathrm{Cd}$} & Min & 0.99 & \multirow{3}{*}{$3-8$} & \multirow{3}{*}{0.3} & 3.29 & 0.34 \\
\hline & Max & 2.31 & & & 7.72 & 0.71 \\
\hline & Mean & 1.78 & & & 5.93 & 0.59 \\
\hline \multirow[t]{3}{*}{$\mathrm{Co}$} & Min & 3.02 & \multirow{3}{*}{$25-50$} & \multirow{3}{*}{19.0} & 0.16 & -0.97 \\
\hline & Max & 9.98 & & & 0.53 & -0.46 \\
\hline & Mean & 6.33 & & & 0.33 & -0.68 \\
\hline \multirow[t]{3}{*}{$\mathrm{Ni}$} & Min & 10.17 & \multirow{3}{*}{$75-100$} & \multirow{3}{*}{68.0} & 0.15 & -1.00 \\
\hline & Max & 26.62 & & & 0.39 & -0.58 \\
\hline & Mean & 16.22 & & & 0.24 & -0.81 \\
\hline \multirow[t]{3}{*}{$\mathrm{Pb}$} & Min & 7.84 & \multirow{3}{*}{$100-400$} & \multirow{3}{*}{17.0} & 0.46 & -0.51 \\
\hline & $\operatorname{Max}$ & 18.94 & & & 1.11 & -0.13 \\
\hline & Mean & 12.53 & & & 0.74 & -0.32 \\
\hline \multirow[t]{3}{*}{$\mathrm{Cr}$} & Min & 10.40 & \multirow{3}{*}{$75-100$} & \multirow{3}{*}{95.0} & 0.11 & -1.14 \\
\hline & $\operatorname{Max}$ & 49.55 & & & 0.52 & -0.46 \\
\hline & Mean & 21.52 & & & 0.23 & -0.84 \\
\hline
\end{tabular}

* Alloway (1995) [13]

** $\mathrm{BV}=$ Background value $[16]$

The heavy metal contamination factor is the ratio of the metal concentration in the soil and the background value for each metal. The index calculation uses heavy metal concentration in nature (background value) as a reference standard to determine a change in heavy metal concentrations in the environment. According to Hans Wedepohl (16), the background value for $\mathrm{Pb} 17 \mathrm{mg} \mathrm{kg}^{-1}, \mathrm{Cd} 0.3 \mathrm{mg} \mathrm{kg}^{-1}$, Co $19 \mathrm{mg} \mathrm{kg}^{-1}$, Ni $68 \mathrm{mg} \mathrm{kg}^{-1}$, and $\mathrm{Cr}$ $95 \mathrm{mg} \mathrm{kg}^{-1}$ (Table 2). The I-geo value in the $\mathrm{Cd}$ parameter indicates the soil category uncontaminated to moderately contaminated. The soils in all studied samples were uncontaminated concerning $\mathrm{Pb}, \mathrm{Co}, \mathrm{Ni}$, and $\mathrm{Cr}$. The PLI value is very low ranges between 0.46-0.78, this indicates that the agricultural soil for shallots in Wanasari Village, Brebes Regency, Central Java Province is classified as uncontaminated [13,17].

Contaminant factor values for heavy metals $\mathrm{Cr}, \mathrm{Co}$, and $\mathrm{Ni}$ are low $(\mathrm{CF}<1), \mathrm{CF}$ of $\mathrm{Pb}$ means moderate contamination, and $\mathrm{CF}$ for $\mathrm{Cd}$ means from high contamination $(3<\mathrm{CF}<6)$ until very high contamination $(\mathrm{CF}>6)$. The I-geo value of the soil samples ranges of -0.51 to -0.13 for $\mathrm{Pb},-0.97$ to $-0,46$ for $\mathrm{Co},-1,0$ to 0,58 for $\mathrm{Ni},-1.14$ to -0.46 for $\mathrm{Cr}$, and $0.34-0.71$ for Cd (Table 2). The PLI value gives the status of heavy metal contamination in the soil.

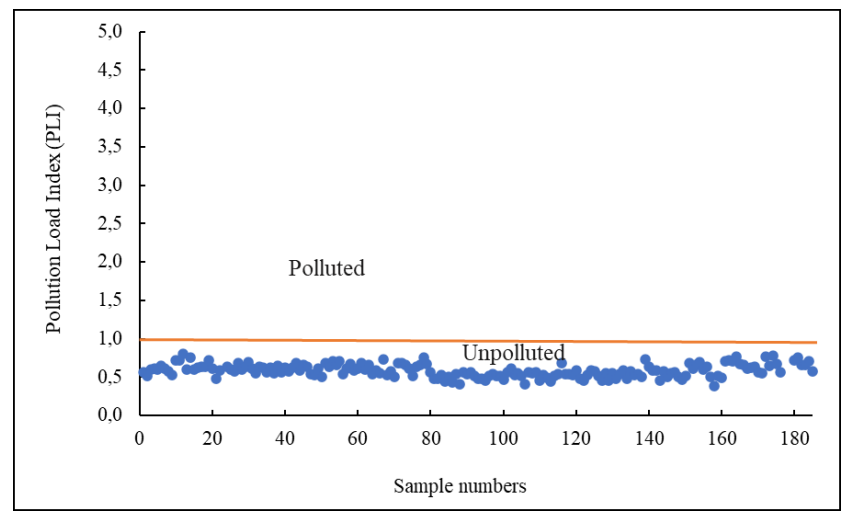

Fig 4. The pollution load index (PLI) in shallot fields, Brebes Regency, Central Java 
The PLI ranged from 0.38 until 0.80 , which means that the overall shallot soil samples in eight sub-districts in Brebes Regency are classified as unpolluted by $\mathrm{Pb}, \mathrm{Cr}, \mathrm{Cd}, \mathrm{Co}$, and $\mathrm{Ni}$ $(\mathrm{PLI}<1)$ (Table 3).

\section{Conclusion}

The concentration of heavy metals in the soils varied as follows $\mathrm{Cr}>\mathrm{Ni}>\mathrm{Pb}>\mathrm{Co}>\mathrm{Cd}$. The heavy metals of $\mathrm{Pb}, \mathrm{Co}, \mathrm{Cd}, \mathrm{Ni}$, and $\mathrm{Cr}$ have low concentrations compared with their critical levels in the soil. Heavy metal contamination indices are needed to effectively quantify the contamination of a given region. This study using a comparative assessment with Contaminant Factor (CF), Geoaccumulation Index (I-geo), and Pollution Load Index (PLI) in shallot fields in Brebes Regency, Central Java. Contaminant Factor (CF) values indicated low contamination $(\mathrm{Pb}, \mathrm{Cr}, \mathrm{Co}$, and $\mathrm{Ni})$, and for $\mathrm{Cd}$ means from high to very high contamination. I-geo showed that the contamination levels ranged from uncontaminated $(\mathrm{Pb}$, $\mathrm{Co}, \mathrm{Cr}$, and $\mathrm{Ni}$ ) to moderately uncontaminated $(\mathrm{Cd})$. The PLI value ranges from $0.38-0.80$ which means in overall soil samples in shallot fields in eight sub-districts, Brebes Regency is classified unpolluted by heavy metals $\mathrm{Pb}, \mathrm{Cd}, \mathrm{Co}, \mathrm{Ni}$, and $\mathrm{Cr}$.

Acknowledgement. The research was funded by Indonesian Agency of Agricultural Research and Development (IAARD) Dissertation Program, Ministry of Agriculture, Indonesia (No.047/Kpts/KP.320/H.1/11/2019) and supported by UGM-RTA 2021 (3190/UN1/DITLIT/DIT$\mathrm{LIT} / \mathrm{PT} / 2021)$. The authors would also like to appreciate the great assistance and cooperation of parties during the research.

\section{References}

1. A. K. Chopra, C. Pathak, G. Prasad, J. Appl. Nat. Sci. 1, 1 (2009)

2. Q. Sun, W. Qi, W. Jiang, Land use assessment using indices of heavy metal contamination in soils from intensive agricultural areas, in Proceedings of the IOP Conf.

Ser. Earth Environ. Sci. 687, 1, 15-17 January 2021, Zhuhai, China (2021)

3. H. Khalilova, V. Mammadov, Polish J. Environ. Stud. 25, 1 (2016)

4. J. Marrugo-Negrete, J. Pinedo-Hernández, S. Díez, Environ. Res. 154 (2017)

5. H. D. Weissmannová, J. Pavlovský, Environ. Monit. Assess. 189, 12 (2017)

6. S. Tong, H. Li, W. Li, M. Tudi, L. Yang, Int. J. Environ. Res. Public Health. 17, 9 (2020)

7. ISRI, Analisis Kimia Tanah, Tanaman, Air, dan Pupuk (Bogor, Indonesia: Indonesian Soil Research Institute, 2009)

8. H. J. O. Zoffoli, N. M. B. Do Amaral-Sobrinho, E. Zonta, M. V. Luisi, G. Marcon, and A. Tolón-Becerra, Environ. Monit. Assess. 185, 3 (2013)

9. M. M. Eliana Andrea, T. E. Ana Carolina, C. B. Tito José, M. N. José Luis, G. M. Luis Carlos, Heliyon. 5, 8 (2019)

10. X. Fei, R. Xiao, G. Christakos, A. Langousis, Z. Ren, Y. Tian, X. Lv, Ecol. Indic. 106, 198 (2019)

11. R. A. Sutherland, Bed sediment-associated trace metals in an urban stream, Oahu, Hawaii (Springer-Verlag, 2000).

12. M. S. Islam, M. K. Ahmed, M. H. Al-Mamun, Pedosph. An Int. J. 29, 5 (2019)

13. B. J. Alloway, Heavy Metals in Soils (Chapman and Hall India, Australia, 1995)

14. A. Keshavarzi, V. Kumar, Geol. Ecol. Landscapes. 4, 2 (2020) 
15. G. Navarrete-Rodríguez, M. D. R. Castañeda-Chávez, F. Lango-Reynoso, Int. J. Environ. Res. Public Health. 17, 3 (2020)

16. K. Hans Wedepohl, Geochim. Cosmochim. Acta. 59, 7 (1995)

17. T. Dewi, E. Martono, E. Hanudin, R. Harini, Heavy metals contamination assessment in agricultural soil for shallot in Wanasari, Brebes Regency, Central Java Province, in Proceedings of the IOP Conf. Ser. Earth Environ. Sci. 752, 1 (2021) 